\title{
PERKEMBANGAN INDUSTRI PERTANIAN DI SARAWAK, 1970-1981
}

\section{DEVELOPMENT OF AGRICULTURE INDUSTRY IN SARAWAK, 1970-1981}

\author{
Emyzul Ismail* \\ Arba'iyah Mohd Noor** \\ Universiti Malaya (UM)
}

\begin{abstract}
Abstrak
Pertanian merupakan antara penyumbang penting kepada kemakmuran ekonomi Sarawak. Industri pertanian di Sarawak telah mengalami pelbagai perubahan sebelum dan selepas kerajaan Sarawak dipimpin oleh Abdul Rahman Ya'kub sebagai Ketua Menteri Sarawak ketiga. Artikel ini memfokuskan perkembangan industri pertanian di Sarawak dari tahun 1970 hingga 1981 sebaik sahaja Abdul Rahman Ya'kub memegang tampuk Kerajaan Negeri Sarawak sebagai Ketua Menteri Sarawak sehinggalah tahun terakhir pemerintahan beliau. Artikel ini ingin melihat sejauh mana peranan agensiagensi yang terlibat dalam membangunkan industri pertanian di Sarawak dalam tempoh yang dinyatakan. Pelbagai strategi yang telah dilaksanakan turut dianalisis berdasarkan masalah yang dikenalpasti. Akhir sekali kesan perkembangan industri ini terhadap pembangunan sosial di negeri Sarawak akan dikenal pasti. Penyelidikan ini menggunakan bahan dan data daripada Arkib Negara Cawangan Sarawak, Arkib Negara Malaysia, Pustaka Negeri Sarawak, Pusat Repositori Pustaka Negeri Sarawak, Perpustakaan DBP Cawangan Sarawak, Perpustakaan Utama Universiti Malaya dan Perpustakaan Za'ba Universiti Malaya. Hasil kajian mendapati, kerjasama antara Kerajaan Negeri Sarawak dengan Kerajaan Persekutuan berjaya meningkatkan KDNK menerusi jumlah pengeluaran dan eksport hasil pertanian. Lebih menarik lagi apabila perkembangan industri pertanian berjaya meningkatkan taraf hidup rakyat Sarawak.
\end{abstract}

Kata kunci: Sarawak, Pertanian, Masalah, Strategi, Kesan

\begin{abstract}
Agriculture is one of major contributors to Sarawak's economic prosperity. The Sarawak agriculture industry has undergone many changes before and after the Sarawak government led by Abdul Rahman Ya'kub as the third Sarawak Chief Minister. This article focuses on the development of the agricultural industry in Sarawak from 1970 to 1981 after Abdul Rahman Ya'kub held the Sarawak State Government as the Chief Minister of Sarawak until the last year of his rule. This article seeks to see the role of the agencies involved in the development of the agricultural industry in Sarawak over the period mentioned. Various strategies that have been implemented are also analyzed based on the identified problems. Finally the impact of this industry on social development in Sarawak will be identified. This research uses materials and data from the National Branch of the Sarawak Branch, National Archives of Malaysia, the Sarawak State Library, the Sarawak State Library Repository, the DBP Library ( Sarawak Branch), the University of Malaya Main Library and the University of Malaya Za'ba Library. The findings show that cooperation between the State Government of Sarawak and the Federal Government has been able to increase GDP through increased production and export of agricultural produce. It is even more interesting that the development of the agricultural industry has improved the quality of life of the people of Sarawak.
\end{abstract}


Keywords: Sarawak, Agriculture, Problems, Strategy, Impact.

\section{Pengenalan}

Sarawak Bumi Kenyalang merupakan sebuah negeri yang terletak di barat laut Pulau Borneo dan menghadap ke Laut China Selatan. Dengan keluasan 124,450 kilometer persegi, Sarawak kemudiannya menjadi negeri terbesar di Malaysia. ${ }^{1}$ Permukaan bumi Sarawak meliputi kira-kira 48,000 batu persegi dengan pantainya kira-kira 500 batu panjang. Bentuk muka bumi Sarawak terdiri daripada kawasan pergunungan di tenggara dan tanah pamah di barat laut. Kawasan sempadannya dengan Kalimantan mempunyai ketinggian di antara 2,500 hingga 4,000 kaki dari paras laut. ${ }^{2}$ Keluasan dan khazanah bumi Sarawak yang begitu kaya telah mendorong kerajaan negeri Sarawak dan persekutuan untuk merancang penubuhan agensi seperti Lembaga Kemajuan Tanah Sarawak atau Sarawak Land Development Board (SLDB) dan Lembaga Penyatuan dan Pemulihan Tanah Sarawak (SALCRA) bagi memastikan pengurusan sektor pertanian yang terurus dan cekap. Topik ini mempunyai signifikan untuk dikaji memandangkan belum ada lagi kajian yang mengkhususkan skop kajian dalam tempoh 1970 hingga 1981 di Sarawak. Kajian ini akan menyentuh aspek pengurusan pertanian, masalah dan strategi mendepaninya, analisis hasil pengeluaran sektor pertanian di samping membincangkan kesan-kesannya terhadap pembangunan sosial Sarawak menerusi dasar ekonomi yang dilaksanakan sebagaimana direncanakan dalam Rancangan Malaysia Kedua dan Ketiga dari tahun 1970 hingga 1981.

Menyedari akan peranan dan signifikannya sektor ini dalam mewarnai ekonomi Sarawak, maka kajian ini melihat perlunya sektor pertanian diangkat sebagai sebagai antara penyumbang kepada sumber ekonomi negeri ini. Sektor pertanian diklasifikasikan sebagai agak istimewa apabila dilihat dari sudut ranking. Menurut Nor Diana Mohd Idris, "Sektor ini sering dikaitkan dengan masalah kemiskinan terutama di kawasan luar bandar yang bergantung kepada pertanian sebagai sumber pendapatan dan kelangsungan hidup. Oleh itu, dalam konteks kesejahteraan alam sekitar dan kualiti hidup dalam kalangan komuniti luar bandar, pengurangan kemiskinan serta peningkatan pendapatan melalui penggunaan sumber yang cekap merupakan jaminan utama kepada hasil penghidupan yang lestari" ${ }^{3}$ Justeru, dalam konteks kajian ini jelas sekali bahawa golongan bumiputera Sarawak berada dalam lingkungan kemiskinan. Hal ini demikian kerana golongan bumiputera Sarawak tanpa mengambilkira sama ada bumiputera Islam ataupun bukan Islam, rata-ratanya hidup dalam kemiskinan pada era tersebut. Atas sebab itulah, Abdul Rahman Ya'kub menegaskan bahawa pada era pemerintahan beliau sebagai Ketua Menteri Sarawak, sektor pertanian terus diberikan perhatian sebagaimana kenyataan berikut, "Adalah penting untuk mengekalkan pertumbuhan dalam sektor pertanian memandangkan kira-kira $80 \%$ penduduk kita berada dalam sektor luar bandar." "Skop kajian sektor pertanian ini merangkumi penanaman getah, kelapa sawit dan lada hitam yang telah dilaksanakan bermula dari tahun 1970 sehingga 1981.

Ringkasnya, peranan yang dimainkan oleh sektor pertanian di Sarawak antara tahun 1970 hingga 1981 tidak boleh dikesampingkan. Hal ini demikian kerana sektor ini didapati turut menyumbang kepada perkembangan ekonomi Sarawak malah menjadi pembekal bahan mentah utama dalam sektor perindustrian pada era tersebut sebagaimana sektor minyak, gas asli dan pembalakan. Usaha-usaha yang dilakukan oleh kerajaan negeri dengan kerjasama kerajaan persekutuan membuktikan bahawa sektor ini kekal relevan untuk menyokong perkembangan ekonomi di samping memenuhi keperluan rakyat Sarawak pada masa tersebut. Hasil kajian menerusi kertas kerja ini mampu memberi gambaran sebenar pencapaian sektor pertanian di Sarawak 
dalam skop masa kajian (1970 hingga 1981) dan yang paling penting menjadi panduan berguna dalam merancang strategi ekonomi dan landskap sosial berkesan pada masa hadapan.

\section{Latar Belakang Kajian}

Peranan SLDB dan SALCRA dalam menambahbaik pengurusan industri pertanian dalam tempoh 1970 hingga 1981 belum dibincangkan oleh mana-mana sarjana. Perkembangan sektor pertanian di Sarawak sebelum 1970 wajar difahami sebelum menelusuri kajian era pentadbiran 1970 hingga 1981. Menelusuri sejarah, ekonomi negeri Sarawak dikategorikan sebagai ekonomi yang berasaskan pertanian dengan aktiviti pertanian dilakukan secara meluas pada zaman Brooke dan kolonial British. Sebelum Penubuhan Persekutuan Malaysia pada 16 September 1963, Sarawak adalah sebuah negara di bawah pentadbiran koloni British selepas berlakunya penyerahan Sarawak daripada pemerintah Brooke pada tahun 1946..$^{5}$ Menurut D.S. Ranjit Singh, beliau mendapati dasar Raja Charles Brooke (1868-1917) iaitu raja putih yang kedua gagal memajukan penanaman padi Sarawak walaupun telah membawa masuk imigran Cina secara besar-besaran bermula pada tahun 1880-an ekoran kecenderungan imigran ini kepada tanaman komersial. ${ }^{6}$ Orang Cina lebih tertarik kepada tanaman-tanaman komersial seperti lada, gambir dan getah dan mengabaikan penanaman padi. ${ }^{7}$ Antara aktiviti pertanian yang dilakukan oleh masyarakat Sarawak ialah penanaman padi, getah, nenas, lada hitam, sagu, kelapa dan buah-buahan serta terlibat dalam bidang perikanan. ${ }^{8}$ Hal ini memberi gambaran jelas bahawa sektor pertanian bukanlah sektor yang asing sebagai penjana ekonomi Sarawak sebelum tahun 1970.

Kajian terhampir berhubung pembangunan ekonomi boleh dilihat menerusi olahan Abdul Hamid Bugo dalam tulisannya, The Economic Development of Sarawak: The Effect of Export Instability. Beliau dilihat membincangkan pembangunan ekonomi Sarawak bermula pada tahun 1964 dan semasa tiga tahun pertama pemerintahan Abdul Rahman Ya'kub. Dengan kata lain, skop masa tersebut hanya melewati sehingga tahun 1973 dan tidak menyentuh perkembangan yang berlaku tahun-tahun selepas itu. Kajian ini hanya melaporkan aktiviti import dan eksport sumber komiditi seperti getah dan kelapa sawit Sarawak dan keuntungan yang diperoleh kerajaan negeri Sarawak antara tahun 1964 hingga 1973. Walau bagaimanapun, kajian ini didapati mengabaikan kesan daripada dasar dan perkembangan ekonomi kepada rakyat keseluruhannya dalam aspek pembangunan infrastruktur dan pendapatan. Sejarah pembangunan ekonomi Sarawak turut dibincangkan dalam buku Sarawak Maju Sejak Merdeka terbitan Kerajaan Negeri Sarawak dan Yayasan Sarawak ${ }^{9}$ Laporan buku ini berlatarbelakangkan sejarah menuju kemerdekaan Sarawak sehinggalah laporan satu dekad pemerintahan kerajaan negeri sebagaimana yang ditetapkan dalam tempoh kajian. Laporan berhubung perkembangan Sarawak bermula dengan pendidikan, pertanian, perindustrian, perkhidmatan kesihatan dan sosial namun dapatannya didapati tidak mendasar.

Satu lagi kajian terhampir tulisan Fumitaka Furuoka membincangkan pembangunan ekonomi Sarawak dalam kajiannya, Economic Development In Sarawak, Malaysia: An Emperical Inquiry. ${ }^{10}$ Kajian ini memfokuskan hubung kait pembangunan ekonomi dengan turun naik pasaran komoditi utama iaitu pertanian, petroleum, gas asli dan pembalakan. Penulis ini juga turut menghubungkait pembangunan ekonomi dengan pertumbuhan penduduk, perbelanjaan mengurus dan perdagangan antarabangsa. Perbincangan terhadap kesan pembangunan ekonomi terhadap perkembangan sosial seperti peluang pekerjaan dan perkembangan infrastruktur turut disentuh tetapi hanya seimbas lalu. Skop kajian pula lebih membincangkan pembangunan ekonomi Sarawak dari tahun 1970 hingga 2003. Perbandingan pendapatan per kapita antara Sarawak dan 
Sabah serta Malaysia keseluruhannya hanya menyentuh dapatan 1970, 1980 dan 1990 tanpa membuat perincian terhadap kesannya terhadap perkembangan sosial. Sementara itu, melalui penulisan Suhaimi Mokhtar, Putera Kenyalang: Satu Dekad Penuh Cabaran cuba memaparkan pengiktirafan terhadap kejayaan pembangunan ekonomi Sarawak semasa era pemerintahan Abdul Rahman Ya'kub sebagai Ketua Menteri Sarawak ketiga, 1970 hingga 1981. Dasar-dasar ekonomi hanya disentuh secara umum oleh kerajaan negeri ini melalui Rancangan Malaysia Kedua 1970 hingga $1975 .{ }^{11}$

Sebagaimana ditegaskan sebelum ini, walaupun kajian tulisan Hamid Bugo, The Economic Development of Sarawak: The effects of export instability 12 telah membincangkan berhubung pembangunan ekonomi Sarawak, 1964-1973, namun kajian ini hanya membataskan skop kajian sehingga tahun 1973. Keadaan ini didapati tidak memadai bagi membolehkan kajian mengenai pembangunan ekonomi kerajaan negeri khususnya industri pertanian Sarawak 1970-1981 diketengahkan memandangkan skop tahun kajian ini akan memberikan bukti signifikan untuk mengukur kejayaan kerajaan yang memerintah pada skop masa kajian. Selain itu, buku terbitan State Government and The Sarawak Foundation, Sarawak Maju Sejak Merdeka, turut memaparkan pelbagai bentuk pembangunan ekonomi dan sosial Sarawak sebagaimana skop tahun dan geografi kajian. Justeru, langkah mengadakan kajian lanjut ini juga sangat penting memandangkan belum ada lagi kajian yang menumpukan secara khusus berhubung kesan pembangunan ekonomi Sarawak antara tahun 1970-1981 terhadap aspek pembangunan sosial.

\section{Pengurusan Sektor Pertanian di Sarawak, 1970-1981}

Abdul Rahman Ya'kub yang memimpin kerajaan negeri Sarawak dari tahun 1970 hingga 1981 menjelaskan bahawa adalah penting untuk mengekalkan pertumbuhan dalam sektor pertanian memandangkan kira-kira $80 \%$ penduduk Sarawak berada dalam sektor luar bandar. Berdasarkan rekod yang diperoleh, 83\% daripada 346,000 pekerja tinggal di luar bandar. ${ }^{13}$ Populasi penduduk yang begitu ramai di luar bandar menjadi penanda aras kepada kerajaan negeri dan persekutuan untuk merancang dan melaksanakan perkhidmatan sebaik mungkin sebagaimana direncanakan dalam RMK2 dan RMK3 dengan tumpuan khusus terhadap pelaksanan Dasar Ekonomi Baru (DEB) mulai tahun 1970 hingga 1990.

Secara tradisinya, pertanian menyediakan asas utama ekonomi sebagai barangan eksport utama selain produk petroleum dan petroleum, termasuk kayu dan pelbagai komoditi seperti getah, lada, tepung sagu, minyak kelapa dan minyak kelapa sawit. Sarawak adalah negeri yang ekonominya berorientasikan eksport dan keadaan ini memerlukan kerajaan bersedia dengan situasi turun naik harga komoditi di pasaran dunia. ${ }^{14}$ Kerajaan negeri sedar bahawa kekayaan hasil pertanian memerlukan pengurusan yang lebih sistematik agar hasil pengeluaran yang dieksport mampu menunjukkan pencapaian yang lebih baik daripada sebelum ini. Untuk merealisasikan matlamat tersebut, kerajaan negeri dengan kerjasama kerajaan persekutuan telah menubuhkan beberapa agensi pengurusan dengan tujuan mencapai objektif pengurusan pertanian yang lebih cekap dan berkesan. 


\section{Penubuhan SLDB}

Pada 1 Februari 1972, ${ }^{15}$ kerajaan negeri Sarawak telah menubuhkan SLDB dalam usaha menjadikan pengurusan sektor pertanian lebih cekap disamping untuk mewujudkan kemajuan sosioekonomi dalam kalangan rakyat sejajar dengan matlamat yang disasarkan menerusi DEB. ${ }^{16}$ SLDB dipertanggungjawab untuk membuka tanah yang belum dimajukan untuk faedah pertanian dengan penanaman getah dan kelapa sawit sebagai projek-projek utama. ${ }^{17}$ SLDB juga bertanggungjawab untuk menempatkan orang-orang yang telah terpilih di Rancangan-Rancangan Kemajuan Tanah yang baharu dibuka supaya keadaan ekonomi peneroka-peneroka lebih kukuh. Untuk menjadikan sektor pertanian lebih berdaya maju, SLDB menyediakan kemudahan-kemudahan pinjaman, perkhidmatan-perkhidmatan pengurusan dan penyeliaan, memproses dan memasar hasil-hasil keluaran para peneroka dan mendirikan kilang-kilang moden. ${ }^{18}$ SLDB bertindak sebagai agensi pembangunan tanah, bertujuan untuk membasmi kemiskinan luar bandar dan menyediakan taraf hidup yang lebih tinggi untuk penduduk desa. Untuk memenuhi rancangan tersebut, kerajaan negeri Sarawak telah memperkenalkan skim penanaman getah dengan menyaksikan pembukaan banyak estet getah. ${ }^{19}$ Buktinya, SLDB telah menyelenggarakan tujuh skim penanaman getah meliputi kawasan seluas 14,266 ekar di Triboh, Melugu, Skrang, Meradong, Sibintek, Lambir dan Lubai Tengah. ${ }^{20}$

Di samping getah, SLDB turut bergiat aktif dalam sektor penanaman kelapa sawit. Sebanyak sembilan skim seumpama itu telah dirancangkan untuk Kompleks Lambir/Subis dan Kompleks Mukah/Balingian, enam darinya telah pun di peringkat pengeluaran. Kejayaan utama SLDB dalam perusahaan kelapa sawit ialah penubuhan kilang memproses Kelapa Sawit Niah yang berharga \$9 juta. Kilang ini berkemampuan memproses 30 tan buah kelapa sawit dalam masa sejam. Begitu juga dengan kilang kedua di kompleks Mukah/Balingian yang berkemampuan memproses 20 tan buah kelapa sawit dalam masa sejam. ${ }^{21}$ Demi mencapai hasrat tersebut, usaha pemuliharaan telah dilakukan oleh kerajaan negeri melalui SLDB dengan membuka 44,000 ekar tanah untuk tujuan pemeliharaan tanaman kelapa sawit. Program ini telah memberi peluang yang sangat luas dalam intersectoral movements dari serendah-rendah kepada produktiviti yang paling tinggi dalam aktiviti pertanian. Pada masa yang sama, kerajaan negeri juga meneruskan penyediaan subsidi untuk beberapa tanaman, penggabungan penyelidikan pertanian, perkhidmatan tambahan dan latihan pertanian yang dianjurkan oleh Jabatan Pertanian termasuk program yang melibatkan saliran dan pengairan yang dianjurkan oleh Jabatan Pengairan dan Saliran. Pemodenan pertanian melalui program seperti ini telah berjaya meningkatkan produktiviti dalam sektor pertanian Sarawak. ${ }^{22}$

Pembukaan ladang kelapa sawit tidak terhad di situ sahaja apabila Saremas Sdn. Bhd. membuka 9,900 hektar dan 4,000 hektar lagi diusahakan oleh Bintulu Luber Sdn. Bhd. Selain itu, Sarawak Pulp Industries Sdn. Bhd. dan Imbok Enterprise Sdn. Bhd. juga membuka ladang kelapa sawit masing-masing seluas 7,300 hektar dan 11,400 hektar. Penanaman rotan turut diusahakan oleh Kerasa Sdn. Bhd. dengan keluasan kawasan penanaman 2,000 hektar. ${ }^{23}$ Pada pertengahan tahun 1970an, SLDB dan Commonwealth Development Corporation telah membuka tanah secara besarbesaran di sepanjang Jalan Bintulu-Miri untuk pembukaan ladang kelapa sawit lebih 20,000 hektar dan ladang koko seluas 1,000 hektar. ${ }^{24}$ Di samping itu, SLDB turut memajukan 43,470 ekar tanah yang meliputi kawasan-kawasan Ulu Mukah dalam bahagian ketiga dan Lambir-Subis bahagian keempat. Kesemua ini ditanam dengan kelapa sawit. $^{25}$

Penubuhan SLDB pada era Abdul Rahman Ya'kub ini menjadi faktor penting kepada perkembangan aktiviti pertanian di Sarawak di samping bagi menambahbaik 
sistem pengurusan pertanian yang kurang cekap sebelum ini. Sejajar dengan matlamat asal penubuhan agensi kerajaan negeri ini, penempatan peneroka-peneroka terpilih di Rancangan-Rancangan Kemajuan Tanah yang baharu dibuka telah menyumbang kepada keadaan ekonomi yang lebih kukuh menerusi jumlah eksport getah dan kelapa sawit yang terus meningkat dari setahun ke setahun. Buktinya, nilai eksport minyak sawit mentah mencatatkan peningkatan nilai eksport sebanyak \$3,154,447 atau $81.1 \%$ pada tahun 1975 berbanding $\$ 732,256$ pada tahun 1974. Ekoran permintaan menggalakkan terhadap minyak sawit mentah, nilai eksport komoditi ini terus merekodkan pencapaian memberangsangkan empat tahun berturut-turut. Dengan mencatatkan perbezaan peningkatan sebanyak $\$ 11,969,376$ atau $61 \%$ dan $\$ 6,823,727$ atau 25.8\% pada tahun 1977 dan 1978, pencapaian baik ini terus meningkat sehingga menunjukkan perbezaan peningkatan sebanyak $\$ 5,734,771$ atau $17.8 \%$ pada tahun 1979 dan $\$ 384,321$ atau $1.1 \%$ pada tahun $1980 .{ }^{26}$ Hal ini sekali gus meningkatkan pendapatan para peneroka menerusi kemudahan-kemudahan pinjaman, perkhidmatanperkhidmatan pengurusan dan penyeliaan, memproses dan memasar hasil-hasil keluaran para peneroka dan mendirikan kilang-kilang.

Tidak cukup dengan itu, SLDB telah memainkan peranan sebagai agensi pembangunan tanah telah berjaya menyediakan taraf hidup yang lebih tinggi untuk penduduk desa. Buktinya, dalam tempoh 1970 hingga 1975, misalnya, sektor ini berkembang pada purata $2.7 \%$ setahun. ${ }^{27}$ Pada tahun 1979 , kira-kira $70 \%$ penduduk aktif dari segi ekonomi terlibat dalam bidang pertanian. Sektor pertanian menghasilkan kira-kira 18\% daripada Keluaran Negara Kasar dan memperoleh kira-kira $27.1 \%$ daripada pendapatan eksport negara. ${ }^{28}$ Malah, sebagai persediaan jangka masa panjang serta untuk mengelakkan kebergantungan kepada hasil kelapa sawit, SLDB juga melaksanakan projek-projek lada, koko dan pelbagai tanaman lain seperti engkabang, buah pahala, cengkih dan kayu jati sebagai sumber ekonomi alternatif. Dalam hal ini, sektor pertanian Sarawak turut melaksanakan pemodenan kaedah-kaedah dan pendekatan dalam merancakkan industri ini. Pendekatan ini bukan sahaja untuk meningkatkan hasil tetapi juga menjadi satu cara untuk menarik minat generasi baharu Sarawak untuk melibatkan diri dalam bidang pertanian dan menikmati hasil dan nikmat daripada pemodenan pertanian. Analisis ini jelas membuktikan kesungguhan kerajaan menjadikan getah dan kelapa sawit sebagai tanaman yang sangat menguntungkan kepada kerajaan menerusi hasil eksport. Di samping mampu meningkatkan pendapatan dan kualiti hidup peneroka seperti mana yang dihasratkan oleh kerajaan. Sekaligus, menjadikan Sarawak lebih maju dalam sektor ini.

\section{Penubuhan SALCRA}

Selain SLDB, kerajaan negeri Sarawak telah menubuhkan Lembaga Penyatuan dan Pemulihan Tanah Sarawak (SALCRA) pada Mei, 1976 sebagai Badan Berkanun Kerajaan di bawah Ordinan Pihak Berkuasa Penyatuan dan Pemulihan Tanah Sarawak, 1976. Objektif utama SALCRA adalah untuk meningkatkan kesejahteraan keseluruhan masyarakat luar bandar melalui pembangunan tanah untuk pertanian ladang. SALCRA memainkan peranan utama dalam pemulihan tanah, mempromosikan projek pembangunan pertanian, penyatuan projek pembangunan dan pelaksanaan skim penambahbaikan. Berdasarkan konsep 'in-situ', projek pembangunan SALCRA dilaksanakan di mana komuniti wujud. The natives contribute their lands while SALCRA provides the expertise and funding. The rights to land are recognized through issuance of land titles to individual owners. Kaum pribumi menyumbang tanah mereka sementara SALCRA menyediakan kepakaran dan dana. Hak kepada tanah diiktiraf menerusi penerbitan hakmilik tanah kepada pemilik individu. ${ }^{29}$ Sejak penubuhan 
ladang kelapa sawit pertama di Lubok Antu pada tahun 1976, 17 ladang lebih banyak telah berkembang, termasuk satu ladang teh, meliputi lebih dari 51,000 hektar kawasan tanah yang membentang dari Lundu hingga Bau, Serian, Sri Aman, Betong dan Saratok ${ }^{30}$ SALCRA juga terlibat dalam pemasaran produk kelapa sawit dan membuat teh, untuk membentuk kitaran perniagaan yang lengkap, dengan itu meningkatkan kecekapan dan keuntungan. ${ }^{31}$

Berbanding SLDB, SALCRA telah memulakan program pengembangan dan kepelbagaian seperti memperbadankan dan mengaktifkan anak syarikat, SALCRA Jaya Sdn. Bhd. (SJSB) untuk menyokong Kumpulan dengan menjalankan aktiviti perniagaan berkaitan pertanian dan logistik, memperoleh Sarawak Fertilizer Sdn. Bhd. (SFSB) untuk menghasilkan dan membekalkan baja untuk estet SALCRA. Selain itu, Penyelidikan dan Pembangunan (R \&D) ditubuhkan untuk kerja-kerja tanaman pokok (Penyelidikan Buluh dan Gaharu). SALCRA juga memulakan Projek Ikan Bersepadu di Batang Ai Lubok Antu dan telah dilantik oleh Kerajaan Negeri sebagai Agensi Pimpinan dan Pelaksana di bawah Kawasan Ekonomi Utama Kebangsaan (NKEA) serta menyediakan Pusat Latihan di Bajo, Lundu. ${ }^{32}$

Sejak penubuhannya, SALCRA telah memainkan peranan penting dalam membangunkan negara dengan tanggungjawab untuk penyatuan, pemulihan dan pembangunan tanah di Sarawak untuk tujuan pertanian dan untuk perkara yang berkaitan dengannya dan bersampingan dengannya. Bekerjasama dengan Anak - Anak Syarikat, SALCRA telah berkhidmat dan sangat menyumbang kepada pembangunan sosioekonomi terutama bagi masyarakat luar bandar. ${ }^{33}$ Sebagai Agensi Kerajaan yang terkemuka dalam pembangunan tanah, objektif utama SALCRA adalah untuk meningkatkan produktiviti jangka panjang dan penggunaan optimum tanah Hak Adat Bumiputera (NCR) yang optimum dengan membangun dan menguruskan pembangunan tanah sedemikian yang kini tidak digunakan, tidak digunakan atau kurang maju ke dalam perladangan yang berdaya maju dari segi sosial dan ekonomi. ${ }^{34}$ SALCRA juga terlibat dalam pemasaran produk kelapa sawit dan membuat teh, untuk membentuk kitaran perniagaan yang lengkap, dengan itu meningkatkan kecekapan dan keuntungan. ${ }^{35}$

Sebagaimana SLDB, SALCRA turut memainkan peranan penting dalam menjadikan pengurusan industri pertanian di Sarawak, 1970 hingga 1981 menjadi lebih efisien. Sesuai dengan objektif utama penubuhannya, SALCRA komited berkhidmat untuk meningkatkan kesejahteraan keseluruhan masyarakat luar bandar melalui pembangunan tanah untuk pertanian ladang. Selain itu, SALCRA turut aktif menerusi aktiviti pemulihan tanah, mempromosikan projek pembangunan pertanian, penyatuan projek pembangunan dan pelaksanaan skim penambahbaikan. Berdasarkan konsep 'insitu', projek pembangunan SALCRA dilaksanakan di mana komuniti wujud. Jadual di bawah menunjukkan pelaksanaan program di bawah kedua-dua agensi ini: 


\section{Jadual 1: Kawasan, Pengeluaran Dan Hasil Per Hektar Kelapa Sawit Di Sarawak, 1970-1981}

\begin{tabular}{|c|c|c|c|c|c|c|}
\hline \multirow[b]{2}{*}{$\begin{array}{c}\text { Tahu } \\
n\end{array}$} & \multicolumn{2}{|r|}{ Estet } & \multicolumn{2}{|c|}{$\begin{array}{l}\text { Skim Tanah } \\
\text { (Di bawah } \\
\text { SLDB \& } \\
\text { SALCRA) }\end{array}$} & \multirow{2}{*}{$\begin{array}{l}\text { Pengeluar } \\
\text { an Segar } \\
\text { (b) } \\
\text { Bunchesn } \\
\text { Buah (tan } \\
\text { metrik) }\end{array}$} & \multirow{2}{*}{$\begin{array}{c}\text { Hasil } \\
\text { per } \\
\text { hektar } \\
(\text { tan } \\
\text { metri } \\
\text { k) }\end{array}$} \\
\hline & No & $\begin{array}{c}\text { Kawasan } \\
\text { penanam } \\
\text { an } \\
\text { (hektar) }\end{array}$ & No & $\begin{array}{c}\text { Kawasan } \\
\text { penanam } \\
\text { an } \\
\text { (hektar) }\end{array}$ & & \\
\hline 1970 & 1 & 599 & 2 & 376 & - & - \\
\hline 1975 & 1 & 3,952 & 9 & 9,492 & 24271 & 6.23 \\
\hline 1976 & 1 & 4,133 & 10 & 10,634 & 42272 & 6.35 \\
\hline 1977 & 1 & 4,143 & 11 & 12,013 & 62153 & 7.51 \\
\hline 1978 & 1 & 4,143 & 13 & 14,450 & 96412 & 8.26 \\
\hline 1979 & 1 & 4,143 & 13 & 16,583 & 112076 & 9.65 \\
\hline 1980 & 1 & 3,931 & 14 & 17,900 & 135373 & 11.97 \\
\hline 1981 & 1 & 3,912 & 15 & 19,274 & 142966 & 10.46 \\
\hline
\end{tabular}

Sumber: Disesuaikan dari Sarawak 20 Tahun 1963-1983, Sarawak Report, (tanpa tarikh), hlm. 234.

Jadual 1 menunjukkan kawasan, pengeluaran dan hasil per hektar kelapa sawit di Sarawak, 1970 hingga 1981. Menurut rekod, Skim Tanah kelolaan SLDB dan SALCRA telah bertambah dari setahun ke setahun dengan begitu ketara berdasarkan pertambahan jumlah tanah dan keluasan yang ditanam dengan tanaman tersebut. Rekod menunjukkan jumlah kawasan yang ditanam dengan kepala sawit pada tahun 1975 telah meningkat dengan begitu ketara daripada 376 hektar kepada 9,492 hektar atau 96\%. Peratusan kawasan penanaman kelapa sawit terus bertambah kepada 1,142 hektar atau $10.7 \%$ pada tahun 1976 dan terus meningkat sebanyak $11.47 \%$ pada tahun berikutnya. Tahun 1978 pula mencatatkan peningkatan kawasan penanaman kelapa sawit sebanyak 2,437 hektar atau $16.8 \%$. Jumlah ini terus menunjukkan bacaan positif pada tiga tahun terakhir pemerintahan kerajaan negeri di bawah pimpinan Abdul Rahman Ya'kub iaitu masing-masing mencatatkan pertambahan keluasan kawasan penanaman sawit sebanyak 2,133 hektar atau $12.8 \%$ pada tahun 1979, 1,317 atau $7.35 \%$ pada tahun 1980 dan 1,374 atau $7.12 \%$ pada tahun 1981. Jumlah kawasan penanaman yang kian bertambah ini sekali gus turut menyumbang kepada peningkatan KDNK negeri bagi tempoh tersebut.

\section{Masalah Pelaksanaan dalam Industri Pertanian dan Strategi Menanganinya}

Industri pertanian menghadapi masalah untuk mendapatkan pekerja yang benar-benar berminat untuk bekerja di ladang-ladang kelapa sawit. Hal ini agak mendukacitakan kerajaan negeri. ${ }^{36}$ Era 1970 -an menyaksikan ramai lepasan sekolah yang menganggur. Untuk mengatasi masalah ini, kerajaan melalui Jabatan Buruh telah merancang strategi untuk membantu mereka yang tidak mendapat pekerjaan. Menurut rekod, seramai 1,275 orang pelajar yang sudah keluar daripada sekolah telah mendaftar diri di jabatan tersebut tetapi masih lagi belum mendapat pekerjaan. Terdapat juga keadaan di mana 
apabila sudah mendapat pekerjaan, mereka tidak melapor semula kepada Jabatan Buruh tentang pekerjaan yang diperoleh. Keadaan ini merumitkan pula sistem pendaftaran di jabatan ini. Satu daripadanya pihak Jabatan Buruh telah pun mengadakan tujuh pusat bagi pendaftar mereka yang hendak mencari kerja di seluruh negeri Sarawak ini. ${ }^{37}$ Susulan daripada jumlah angka penganggur yang ramai, kerajaan telah membuat ketetapan berikut:

\begin{abstract}
"Bagi kita, Kerajaan Negeri Sarawak pula, sebagaimana Y.B. tahu, kita mengadakan beberapa latihan di beberapa pusat supaya belia-belia dapat diberi serba sedikit kemahiran dalam segi bercucuk tanam. Kita mempunyai Agricultural Training Centres di beberapa tempat di seluruh negeri kita ini dan rancangan ini nampaknya berjalan dengan memuaskan sungguhpun memang ada pembaharuan-pembaharuan dari semasa ke semasa yang patut dibuatkan.. Jadi, kerajaan sangat menggalakkan di negeri kita ini supaya belia-belia kita yang keluar daripada sekolah yang cenderung sungguh kepada pertanian supaya mereka berkecimpung dalam bidang ini. Salah satu daripada sumber tempat mereka ini boleh mencari kerajaan ialah dalam rancangan-rancangan kemajuan tanah di negeri kita ini." 38
\end{abstract}

Kenyataan di atas jelas membuktikan kesungguhan kerajaan untuk membantu mereka yang tidak bekerja untuk membina mahupun meningkatkan pengetahuan mereka dalam bidang pertanian yang sangat memerlukan mereka yang berkelayakan dan mempunyai pengetahuan dalam bidang tersebut. Strategi ini amatlah signifikan bagi mendepani masalah mendapatkan pekerja.

Di samping itu, kerajaan turut mengutamakan pengambilan pekerja dari negeri Sarawak untuk bekerja di skim-skim kelapa sawit daripada menawarkan pekerjaan kepada pekerja asing. Walau bagaimanapun, kerajaan negeri terpaksa berbuat demikian sekiranya warga tempatan bersikap terlalu memilih pekerjaan. ${ }^{39}$ Dalam konteks menjadikan pertanian sebagai satu kerjaya, Menteri Pertanian dan Pembangunan Komuniti, Dr. Wong Soon Kai menegaskan bahawa kerajaan negeri Sarawak telah mengorak langkah dengan memperkenalkan beberapa program belia. Pertama, kerajaan negeri telah mewujudkan institusi latihan berasaskan pertanian di bawah Program Latihan Pertanian yang telah dilaksanakan sejak tahun 1964. Program ini dibahagikan kepada dua jenis latihan iaitu latihan praktikal pertanian selama 14 minggu dengan menjadikan lepasan sekolah rendah sebagai kumpulan sasaran. Selain itu, kerajaan negeri turut memperkenalkan kursus pertanian umum selama setahun untuk lepasan sekolah menengah dengan kelayakan sekurang-kurangnya tingkatan tiga. $^{40}$

Isu pekerja yang kurang berkemahiran dalam bidang pertanian turut menjadi masalah. Menurut Tun Pehin Sri Haji Abdul Taib Mahmud, cita-cita tinggi Ketua Menteri Sarawak ketiga, Abdul Rahman Ya'kub untuk membangunkan Sarawak telah menampakkan hasil sebaik sahaja Sarawak membuat keputusan bergabung dengan Semenanjung, Sabah dan Singapura untuk membentuk Malaysia. ${ }^{41}$ Walau bagaimanapun, beliau yang juga salah seorang menteri dalam kabinet Abdul Rahman Ya'kub pada ketika itu menegaskan bahawa usaha untuk membangunkan mana-mana industri termasuklah sektor pertanian adalah sangat mengambil masa dan memerlukan kesabaran dan ketelitian dalam memastikan projek yang dirancang boleh dilaksanakan dengan berkesan. ${ }^{42}$ Bagi menangani isu ini, kerajaan telah melancarkan Youth Agricultural Schemes. Ketua Menteri pada ketika itu, Abdul Rahman Ya'kub secara prinsipnya telah bersetuju untuk memberikan peruntukan bagi melancarkan perlaksanaan skim ini. ${ }^{43}$ 
Sehingga 18 Disember 1975, kerajaan negeri Sarawak telah mewujudkan sembilan Pusat Latihan Pertanian di Sarawak. Menurut beliau lagi, kerajaan negeri turut memperkenalkan institusi bukan berasaskan pertanian kepada ahli persatuan belia seperti Saberkas di bawah Rural Youth Extension Services. Di bawah program ini, golongan belia di luar bandar digalakkan untuk menyertai projek pertanian secara berkumpulan dan individu dengan pengawasan oleh Agricultural Extension Staff. Bagi belia yang dilihat mempunyai potensi dalam bidang kepimpinan, mereka akan dipilih menyertai latihan sebagai ketua projek pertanian dengan dibekalkan ilmu pengetahuan berhubung menambahbaik kaedah penanaman. Ilmu yang diperoleh perlu dipanjangkan pula dengan anak buah masing-masing. ${ }^{44}$ Buktinya, sebagai langkah pelaksanaan, Youth Settlement Scheme telah diwujudkan di Pujut/Lopeng, Miri dengan meletakkan seramai 60 orang belia sebagai persediaan menjadikan mereka petani yang cekap. ${ }^{45}$ Usaha ini amat penting bagi mengelakkan kebergantungan dengan pekerja asing.

Di samping itu, sebagai usaha menggalakkan lebih ramai rakyat Sarawak untuk terlibat dalam sektor pertanian, kerajaan negeri telah memperkenalkan School Gardening Programme di sekolah-sekolah yang terletak di luar bandar. Bagi memastikan program ini mencapai objektif yang digariskan, khidmat nasihat dan bantuan material telah disediakan oleh Jabatan Pertanian sebagai langkah menggalakkan orang ramai untuk mengusahakan projek-projek pertanian. ${ }^{46}$

Dari segi pendapatan rakyat, oleh sebab kita mempunyai berbagai-bagai skim: skim pertanian, subsidi lada, subsidi koko, subsidi kelapa, subsidi kepada petani dan peladang menjadikan pendapatan rakyat meningkat naik dan ini menunjukkan perbezaan jurang antara yang berada dengan yang tidak berada berkurangan sedikit walaupun tidak banyak boleh dibanggakan. Dalam hal ini, Abdul Rahman Ya'kub selaku KetuaMenteri Sarawak menzahirkan kekesalan beliau terhadap sikap dan pemikiran sesetengah individu yang kurang matang sebagaimana berikut:

"Kalau kita banding misalnya orang-orang kita Melayu dengan orangorang keturunan Cina atau Iban maka jelas mereka yang bukan Melayu itu jauh lebih maju dalam bidang pertanian dengan jumlah subsidi yang sama. Orang Cina dan Iban sungguh rajin bekerja, sedangkan orang Melayu kurang sedikit. Jadi satu faktor yang harus kita akui ialah limitation atau batas yang dihadapi oleh Bumiputera sendiri dalam merapatkan jurang perbezaan antara yang berada dengan tidak berada akan memakan masa yang panjang dan tidak dapat diselesaikan dalam masa 20 hingga 30 tahun.," 47

Kenyataan di atas jelas menggambarkan kekecewaan beliau memandangkan pelbagai usaha telah dilaksanakan untuk membantu mereka yang menganggur namun faktor sikap telah meletakkan golongan ini terus ketinggalan dalam bidang pertanian. Abdul Rahman Ya'kub ketika ditanya wartawan berhubung isu pengangguran menjelaskan bahawa Sarawak bukan menghadapi masalah pengangguran dalam ertikata yang sebenarnya. Masalahnya ialah under employment bukannya unemployment. Unemployment banyak berlaku disebabkan belia-belia yang dulunya tidak dapat masuk ke Tingkatan 1 kerana tidak lulus Darjah 6 enggan bekerja di ladang-ladang sebagai petani ataupun di laut sebagai nelayan. "Bila saya tubuh Lembaga Kemajuan Tanah Negeri Sarawak saya telah memberi arahan kepada pengerusinya supaya membawa beberapa bilangan anak-anak muda dari Kuching menjadi petani dalam rancangan kelapa sawit. Ramai yang menolak dan kalau adapun yang pergi cuma untuk beberapa ketika sahaja paling lama dua bulan. Mereka segera tinggalkan ladang dan kembali ke Kuching kerana mereka lebih suka memilih blue colour job sebagai anak pejabat walaupun dengan gaji yang kecil. Itulah masalah yang 
kita hadapi kerana pandangan dan sikap anak-anak muda kita ini belum dapat dirombak. Dengan pembangunan yang besar di kawasan Bintulu, masalah yang sama akan timbul kerana kita bukan sahaja kekurangan tenaga mahir, setengah mahir tapi juga buruh kasar." 48 Jelas sekali bahawa masalah sikap turut menyumbang kepada masalah pengangguran. Sikap ini perlu dikikis dalam kalangan pekerja khususnya pekerja tempatan kerana kerajaan telah menyediakan pelbagai peluang pekerjaan yang boleh meningkatkan taraf hidup masing-masing.

Persepsi negatif terhadap bidang pertanian juga perlu dikikis. Sikap memandang rendah terhadap sektor pertanian sebagai pekerjaan yang tidak selesa, kerja dalam cuaca panas dan kotor perlu dibuang. Masyarakat juga perlu disedarkan bahawa bidang pertanian mempunyai faedah yang sangat tinggi. Pendidikan boleh digunakan sebagai alat untuk mengubah imej bidang pertanian yang sering dikaitkan dengan kemiskinan. Sebagai perbandingan, di Filipina, matapelajaran pertanian telah diajar sejak dibangku sekolah lagi. Melalui pembelajaran, pelajar-pelajar didedahkan dengan kepentingan pertanian. ${ }^{49}$ Kewujudan pendidikan pertanian di sekolah menjadi tapak penyediaan sumber tenaga manusia dalam sektor pertanian yang kemudiannya akan diteruskan oleh pusat pengajian tinggi dalam melahirkan golongan profesional dan teknokrat dalam bidang pertanian. Hal ini sejajar dengan dasar pertanian negara yang mahukan penggembelengan sumber-sumber negara secara cekap dan berkesan.Kursus yang ditawarkan oleh sekolah-sekolah berkaitan dengan pendidikan adalah seperti sains pertanian, teknikal pertanian dan vokasional pertanian. Pelajar ini akan didedahkan dalam bidang kerjaya pertanian, maka peluang untuk mendapat pekerjaan dan melanjutkan pelajaran yang lebih tinggi dapat ditingkatkan di kalangan pelajar. Hal ini selanjutnya akan mengurangkan masalah pengangguran yang semakin tenat dalam negara kita. ${ }^{50}$ Menurut Zawani Anis Ismail, pengenalan pendidikan pertanian di sekolah-sekolah telah menjadi teras untuk melahirkan tenaga manusia yang berkualiti. Kecemerlangan murid ini kemudiannya diteruskan sehingga ke peringkat yang lebih tinggi dalam bidang pertanian. Hasilnya, sektor ini boleh berbangga dengan kelahiran golongan professional dan teknokrat dalam bidang pertanian. Keadaan ini sekali gus menepati objektif yang terkandung dalam Dasar Pertanian Negara iaitu memastikan sumber-sumber negara diuruskan secara cekap dan berkesan.

Beberapa kelemahan struktur yang masih terdapat dalam industri pertanian memerlukan penyelesaian segera. Masalah kekurangan buruh dan purata umur mereka yang terlalu tinggi telah mengakibatkan kos purata pengeluaran meningkat, yang seterusnya mengancam kedudukan faedah berbanding negara ini di dalam pengeluaran dan eksport komoditi utama di dunia. Langkah sementara yang sedang diamalkan sekarang dengan mengambil buruh-buruh imigran masih jauh daripada satu penyelesaian yang muktamad. Malah, sifat buruh-buruh ini yang sering berpindahrandah kerana mencari persekitaran yang lebih selesa bukan sahaja mengakibatkan timbulnya masalah pengurusan estet, bahkan dalam jangka panjang, boleh mengancam kedudukan ekonomi estet-estet pertanian. ${ }^{51}$

Selain isu pengangguran, masalah tanah terbiar khususnya di kawasan luar bandar turut membelenggu kerajaan. Kerajaan mendapati tanah-tanahnya yang produktif didapati terbiar dan tidak dibangunkan secara teratur untuk mengeluarkan hasil yang memuaskan. Kajian mendapati kebanyakan tanah kepunyaan kaum bumiputera khususnya di luar bandar adalah ketinggalan dalam banyak bidang pembangunan, ekonomi mahupun sosial. Salah satu punca yang menjadi penyebab kepada masalah ini adalah tradisi penduduk-penduduk luar bandar yang tidak menetap di satu tempat ditambah pula dengan kaedah bercucuk tanam mereka yang tidak sistematik. ${ }^{52}$ Masalah ini terus menjadi penyumbang kepada ketidakstabilan ekonomi dan pendapatan dalam kalangan petani luar bandar ekoran hasil tanaman yang seolah- 
olah dikekalkan peranannya sekadar untuk tanaman sara diri rentetan hasil yang tidak memuaskan. Hal ini mengekalkan golongan petani luar bandar dengan taraf hidup yang sama malah mewarisi kemiskinan nenek moyang mereka. Seperkara lagi ialah keadaan tanah yang berbukit-bukau pula menambahkan lagi kesukaran untuk mengusahakannya. ${ }^{53}$

Bertindak atas masalah-masalah yang telah dikemukakan, kerajaan negeri di bawah pimpinan Ketua Menteri Sarawak ketiga, Abdul Rahman Ya'kub telah mengambil inisiatif memikirkan strategi terbaik bagi memperbaiki keadaan untuk kesejahteraan rakyat. Beliau sedar bahawa sekiranya tiada langkah diambil bagi mengubah corak pemikiran dan budaya pertanian tersebut, maka kaum bumiputera di negeri ini tidak mungkin mengecap kemajuan dan kemewahan yang sepatutnya mereka kecapi. ${ }^{54}$

Justeru, sejajar dengan usaha kerajaan untuk memajukan tanah-tanah yang subur di negeri ini termasuk tanah-tanah di bawah Hak Adat Bumiputera, sama ada yang belum dimajukan atau yang telah dimajukan tetap tidak sempurna pelaksanaannya, SALCRA memainkan peranan sebagaimana tujuan penubuhannya. ${ }^{55}$ Salah satu peranan SALCRA yang paling penting adalah pengambilalihan dana dari Kerajaan Persekutuan dan Kerajaan Negeri untuk membiayai projek pembangunan tanahnya yang secara efektif dapat melepaskan pemilik tanah atau peserta pembangunan tinggi dan kos permulaan. ${ }^{56}$ Selain itu, salah satu strategi SALCRA yang paling berkesan setakat ini adalah pembangunan berskala besar dan sistematis Tanah Hak Adat Bumiputera atau tanah NCR secara komersial. ${ }^{57}$

Untuk mencapai tujuan tersebut, lembaga ini mendorong kaum Iban mempertingkatkan cara pengeluaran pertanian. Rekod menunjukkan dari penghujung tahun 1970 hingga awal 1980, SALCRA telah memajukan 3,000 ekar tanah bagi rancangan penanaman getah di Nanga Skuau berdekatan dengan Sibu. Rancangan ini melibatkan 473 keluarga Iban dari 16 buah rumah panjang dan setiap keluarga diperuntukkan 4.5 ekar tanah ladang getah. Dalam estet getah yang luas itu disediakan bekalan air dan elektrik; pusat perubatan; sebuah sekolah rendah dan Pusat Kawalan Pengakap Sempadan. Bukti tersebut menunjukkan cara hidup orang Iban di rumah panjang dipengaruhi oleh proses pembandaran dan teknik pengeluaran pertanian mereka telah dimodenkan. ${ }^{58}$

Di samping itu, langkah yang boleh diambil untuk menyelesaikan masalah ini adalah dengan mewujudkan persekitaran pekerjaan dan kehidupan yang lebih selesa dengan tawaran gaji yang lebih menarik dan berdaya saing. Strategi sebegini sudah pasti akan menarik minat lebih ramai golongan muda untuk menyertai sektor ini. Untuk mengatasi masalah kekurangan buruh pula, kerajaan perlu menaiktaraf kaedah penanaman dengan memperkenalkan jentera pertanian yang lebih canggih di ladangladang pertanian termasuklah penggunaan lain-lain teknik pengeluaran berintensifkan modal untuk mengatasi masalah kekurangan buruh. Hal ini secara langsung dapat meningkatkan daya keluaran setiap buruh. Langkah kedua ini mestilah disusuli dengan penyatuan unit-unit pertanian yang tidak ekonomik kepada unit-unit yang lebih besar dan menguntungkan. ${ }^{59}$

\section{Kesan dan Implikasi Pemerkasaan Industri Pertanian Di Sarawak, 1970-1981}

Industri Pertanian Berperanan Penting Menyumbang kepada pertumbuhan KDNK Sarawak. Majoriti penduduknya sangat bergantung kepada pertanian untuk mencari nafkah mereka. ${ }^{60}$ Buktinya, sebagai negeri pengeluar lada hitam terbesar di Malaysia, Sarawak mendominasi $96 \%$ daripada jumlah keluasan penanaman lada hitam atau kirakira 12,260 hektar berbanding 3\% atau 345 hektar di Sabah dan 1\% atau 150 hektar di 
Johor. Perlu ditekankan di sini bahawa lada hitam merupakan sumber pendapatan yang penting bagi ekonomi Malaysia dengan Singapura bertindak sebagai pasaran utama di samping Jepun, Jerman Barat, Hong Kong, United Kingdom, Taiwan dan Korea. Walaupun harga lada hitam tidak stabil dengan purata harga kira-kira $\$ 560 / 100 \mathrm{~kg}$ bagi lada putih dan kira-kira $\$ 340 / 100 \mathrm{~kg}$ bagi lada hitam namun dalam konteks kajian ini, jelas memperlihat dominasi dan sumbangan Sarawak dalam peningkatan ekonomi negeri dan negara amnya. ${ }^{61}$ Jadual di bawah pula menunjukkan hasil eksport lada hitam Sarawak:

Jadual 2 : Eksport Lada Hitam Sarawak, 1970-1981

\begin{tabular}{|l|l|l|l|}
\hline \multirow{2}{*}{ Tahun } & \multicolumn{3}{|l|}{ LADA HITAM } \\
\cline { 2 - 4 } & $\begin{array}{l}\text { Jumlah } \\
\text { Eksport } \\
\text { (Tan) }\end{array}$ & $\begin{array}{l}\text { Nilai } \\
\text { Eksport } \\
\mathbf{( \$ )}\end{array}$ & $\begin{array}{l}\text { Nilai Unit } \\
\text { (\$ per tan) }\end{array}$ \\
\hline 1970 & 15,028 & $31,103,304$ & 2,070 \\
\hline 1971 & 17,943 & $38,173,889$ & 2,128 \\
\hline 1972 & 15,922 & $29,287,919$ & 1,839 \\
\hline 1973 & 12,294 & $27,848,915$ & 2,265 \\
\hline 1974 & 15,872 & $46,876,735$ & 2,953 \\
\hline 1975 & 20,553 & $61,854,341$ & 3,010 \\
\hline 1976 & 25,643 & $83,104,659$ & 3,241 \\
\hline 1977 & 19,432 & $90,208,337$ & 4,642 \\
\hline 1978 & 22,133 & $82,397,031$ & 3,723 \\
\hline 1979 & 25,523 & $83,099,527$ & 3,256 \\
\hline 1980 & 22,668 & $68,791,253$ & 3,035 \\
\hline 1981 & 20,006 & $47,939,067$ & 2,396 \\
\hline
\end{tabular}

Sumber: Disesuaikan dari (Tanpa penulis), Sarawak 20 Tahun 1963-1983, Sarawak Report, (tanpa tarikh), hlm. 251. / Jabatan Statistik Negeri Sarawak

Jadual 2 menunjukkan nilai eksport hitam di Sarawak antara tahun 1970 hingga 1981. Nilai seunit lada hitam didapati berubah-ubah mengikut permintaan pasaran semasa. Tahun 1971 menyaksikan nilai eksport lada hitam meningkat sebanyak \$7,070,585 atau $18.5 \%$. Namun, situasi ini tidak kekal lama apabila berlakunya penyusutan sebanyak $\$ 8,885,970$ atau $23.2 \%$ pada tahun 1972 dan $\$ 1,439,004$ atau $4.9 \%$ pada tahun berikutnya disebabkan faktor kejatuhan harga semasa. Walau bagaimanapun, kecekapan aktiviti pemasaran melalui peranan yang dimainkan oleh SLDB dan SALCRA di samping pertambahan jumlah jalan raya di luar bandar menyaksikan nilai eksport meningkat dengan begitu memberangsangkan pada tahun-tahun berikutnya. Buktinya, pada tahun 1974, nilai eksport lada hitam merekodkan pertambahan sebanyak $\$ 19,027,820$ atau $40.5 \%$. Hal ini diikuti sebanyak $\$ 14,977,606$ atau $24.2 \%$ dan $\$ 21,250,318$ atau $25.5 \%$ masing-masing pada tahun 1975 dan 1976. Jumlah ini terus meningkat sebanyak $\$ 7,103,678$ atau $7.8 \%$ pada tahun 1977 . Kejatuhan harga bagi se tan lada hitam pula memperlihat nilai eksport lada hitam mencatatkan sedikit penurunan iaitu $\$ 7,811,306$ atau $8.6 \%$ dan $\$ 702,496$ atau $0.8 \%$ masing-masing pada tahun 1978 dan 1979. Faktor yang sama turut menyebabkan nilai eksport terus merudum kepada $\$ 14,308,274$ atau $20.7 \%$ pada tahun 1980 dan $\$ 20,852,186$ atau $30.3 \%$ pada tahun 1981. Justeru, walaupun menunjukkan penurunan, hasil eksport lada 
hitam tetap berperanan dan menyumbang kepada pembangunan ekonomi pertanian negeri Sarawak sepanjang tempoh kajian.

Ringkasnya, kadar pertumbuhan purata adalah $2.7 \%$ setahun dari segi sebenar antara 1971-1975 dan 3.3\% antara 1976 hingga 1980 dengan pengeluaran pada harga tetap bernilai \$147 juta pada tahun 1971 dan \$192 juta pada tahun 1980. Dari segi bahagiannya dalam KDNK, sektor pertanian merupakan bahagian tertinggi sehingga tahun 1971. ${ }^{62}$ Analisis ini jelas menunjukkan industri pertanian telah menyumbang kepada peningkatan KDNK.

Peranan yang dimainkan oleh SLDB dan SALCRA bukan sahaja menyumbang kepada peningkatan ekonomi negeri tetapi juga menyaksikan perkembangan infrastruktur menyeluruh impak daripada keperluan industri pertanian. ${ }^{63}$ Kerajaan negeri sangatmengambil berat keperluan rakyat yang amat mendahagakan pelbagai kemudahan dalam memudahkan aktiviti pertanian dan ekonomi yang lain. ${ }^{64}$ Kemudahan ini juga memenuhi keperluan-keperluan pentadbiran, perdagangan dan perindustrian. ${ }^{65}$ Untuk itu, pelbagai usaha memperluas dan memperbaiki sistem pengangkutan telah dijalankan di bawah RMK3 yang meliputi jaringan pelabuhan, lapangan terbang, jalan raya terutamanya bagi kawasan-kawasan pembangunan pertanian untuk memudahkan pembangunan ekonomi serta penyatuan sosial dan politik. Program-program pembangunan jalan termasuk kerja-kerja memperbaiki dan meninggikan mutu jalan-jalan besar untuk menghubungkan pusat-pusat kediaman penduduk yang besar, jalan masuk ke pelabuhan-pelabuhan dan kawasan-kawasan perusahaan serta jalan-jalan kecil ke kawasan-kawasan dan pertanian yang baharu. ${ }^{66}$

Perkhidmatan udara di luar bandar dan pengangkutan melalui sungai telah diperluaskan untuk memenuhi keperluan pengangkutan bagi kawasan-kawasan pedalaman. Semua ini telah dicapai melalui pembinaan jeti-jeti di bahagian sungai dan lapangan terbang luar bandar yang baharu di kawasan-kawasan yang masih belum dapat dimasuki dengan menggunakan pengangkutan darat. ${ }^{67}$ Sebagai contoh, pembinaan Jalan Ulu Batang Mukah/Sungai Arip sepanjang 30 batu telah berjaya disiapkan. Projek-projek utama lain yang telah disiapkan termasuklah jalan besar MiriBintulu, Jalan Matang/Istana termasuk sebuah jambatan merintangi Sungai Sarawak di Satok, Kuching dan Jalan Bintulu/Tanjung Kidurong. Jalan Matang/Istana telah menjadi satu jalan masuk yang penting untuk pembangunan kawasan tebing utara bandar Kuching, manakala Jalan Bintulu/Tanjong Kidurong akan menyediakan kemudahan jalan masuk ke pelabuhan baru dan loji gas asli cecair (LNG). ${ }^{68}$ Hal ini membuktikan pembangunan infrastruktur turut mengambil kira keperluan industri lain selain sektor pertanian. Sebelum ini, hasil-hasil pertanian sukar untuk dipasarkan ekoran keadaan perhubungan jalan raya yang sangat terbatas. Menurut Fong Hon Kah, jalan raya perlu dibina untuk memperbaiki perhubungan darat dengan bandar-bandar utama di samping sangat bermanfaat kepada penduduk kampung. ${ }^{69}$ Sanib Said turut senada dalam hal ini. Beliau menyatakan bahawa masalah yang sering diutarakan rakyat Sarawak kepada pemerintah adalah berhubung isu pengangkutan, kemiskinan, kemunduran khususnya di kawasan luar bandar. ${ }^{70}$

Untuk membuktikan keseriusan kerajaan, projek pembinaan jalan raya dan jambatan di kawasan luar bandar telah dilaksanakan iaitu di Jalan Sekati, Lundu, Bahagian Pertama (sekarang dikenali sebagai Bahagian Kuching) untuk membantu rakyat serta memenuhi keperluan sektor pertanian. Mengikut peruntukan, anggaran kos pembinaan adalah sebanyak $\$ 227,500$ manakala loji dan peralatan bernilai $\$ 45,500$ dengan anggaran kos keseluruhan $\$ 273,000$ pada tahun $1978 .{ }^{71}$ Projek ini melibatkan pembinaan satu batu jalan pedalaman yang menghubungkan Kampung Sekati dengan Pekan Lundu. Pembinaan jalan ini bermanfaat untuk menghubungkan bandar dan kampong dengan populasi sekitar 800 orang. Lundu yang terkenal dengan aktiviti pertanian telah mendapat rahmat ekonomi apabila jalan raya yang telah siap 
membolehkan penduduknya memasarkan hasil pertanian mereka di kawasan Pekan Lundu mahupun terus ke bandar Kuching sebagaimana kenyataan di bawah:

"This project would involve the construction of about 11/2 mile of rural road linking Kampung Paon and Kampung Sebako with Lundu/Serayan Road. The proposed road would branch off from mile 11/2 Lundu/Serayan Road. On completion the road would enable the 700 inhibitants of these two kampongs to bring their agricultural products to the market."72

Bagi projek pembinaan jalan raya dan jambatan oleh Jabatan Kerja Raya (JKR), Sarawak di kawasan luar bandar iaitu, di Jalan Sebako, Lundu, Bahagian Pertama, anggaran kos pembinaan, $\$ 225,000$ manakala plant requirement, $\$ 45,000$ dan jumlah keseluruhan projek berjumlah $\$ 270,000$ dijangka siap pada tahun $1978 .{ }^{73}$ Projek ini melibatkan pembinaan kira-kira $11 / 2$ batu jalan pedalaman yang menghubungkan Kampung Paon dan Kampung Sebako dengan Lundu / Jalan Serayan. Jalan yang dicadangkan bermula dari kilometer 11/2 Lundu / Jalan Serayan. Jalan raya baharu ini membolehkan 700 penduduk dari kedua-dua kampung untuk membawa produk pertanian mereka ke pasaran. Perkembangan positif ini ternyata telah meningkatkan pendapatan petani sekaligus meningkatkan taraf dan kualiti hidup mereka. Jadual di bawah membuktikan berlakunya perubahan status kemiskinan rakyat Sarawak:

Jadual 3: Peratusan Sarawak Kadar Kemiskinan Mengikut Kawasan Bandar dan Luar Bandar, 1976 dan 1979

\begin{tabular}{|l|l|l|}
\hline Strata & $\mathbf{1 9 7 6}$ & $\mathbf{1 9 7 9}$ \\
\hline Sarawak & 56.5 & 47.7 \\
\hline Bandar & 22.8 & 17.8 \\
\hline Luar Bandar & 64.4 & 56.0 \\
\hline
\end{tabular}

Sumber: Jomo K.S., Malaysia:Pembangunan, Ketidaksamaan, Perpaduan, Kuala Lumpur: Institut Pengajian Tinggi, Universiti Malaya, 1992, hlm. 69.

Nota:1976 : Berasaskan Banci Pertanian, 1977.

1979 : Berasaskan Penyiasatan Tenaga Buruh/Pendapatan Isi Rumah

Jadual 3 menunjukkan kadar kemiskinan di kawasan bandar dan luar bandar di Sarawak pada tahun 1976 dan 1979. Sarawak dilaporkan mempunyai kadar kemiskinan sebanyak 56.5\% pada tahun 1976 tetapi menunjukkan penurunan pada tahun 1979 sebanyak 8.8\%. Hal ini disebabkan pembangunan infrastruktur menyeluruh melibatkan pembinaan jalan raya, pewujudan bandar baru, penambahbaikan pengangkutan air, pembinaan pelabuhan dan pembinaan lapangan terbang serta padang terbang di seluruh Sarawak. Pembangunan infrastruktur seumpama ini diterjemahkan pula dengan pembangunan ekonomi yang memberi peluang pekerjaan kepada penduduk tempatan. Jika dilihat pula di kawasan bandar,peratusan kemiskinan juga semakin menurun sebanyak 5\% dengan mencatatkan $22.8 \%$ pada tahun 1976 kepada 17.8\% pada tahun 1979 manakala kemiskinan di luar bandar turut merekodkan corak serupa apabila mencatatkan penurunan kadar kemiskinan sebanyak $8.4 \%$ daripada 64.4\% pada tahun 1976 kepada 56.0\% . Dalam hal ini, Jomo dalam kajiannya melihat isi rumah miskin luar bandar meliputi sebahagian besar daripada jumlah isi rumah 
miskin di seluruh Malaysia, iaitu 85-90 peratus sejak tahun 1976. Kadar kemiskinan bandar dan luar bandar di Sarawak terus menurun selepas tahun $1976 .{ }^{74}$ Kadar kemiskinan yang terus menurun ini jelas membuktikan usaha membangunkan Sarawak oleh kerajaan negeri Sarawak dan persekutuan telah menampakkan hasil dalam 11 tahun tempoh pemerintahan Abdul Rahman Ya'kub sebagai Ketua Menteri.

Di samping itu, penyediaan perumahan serta pembekalan elektrik, air dan kemudahan lain untuk masyarakat di Sarawak dijalankan dengan lebih intensif sejurus selepas Malaysia ditubuhkan. Kerajaan Negeri telah menceburi pelbagai aktiviti ekonomi baru yang berjaya meningkatkan produktiviti sektor pertanian dan perindustrian. ${ }^{75}$ Sebagai contoh, kelapa sawit bukan sahaja telah mengubah landskap fizikal Sarawak, ia juga mentransformasikan landskap ekonomi bagi penduduk luar bandar Sarawak. ${ }^{76}$ Sepanjang tiga dekad yang lepas, kejayaan program ini untuk menukar tanah pribumi yang terbiar kepada tanah pertanian yang produktif telah membawa kepada skala pembangunan luar bandar yang lebih besar, pembasmian kemiskinan dan penciptaan peluang pekerjaan yang kemudian membantu meningkatkan taraf hidup dalam kalangan penduduk pribumi khususnya di kawasan-kawasan luar bandar. ${ }^{77}$

\section{Kesimpulan}

Secara ringkasnya, sektor pertanian telah menjadi antara penyumbang terpenting dalam ekonomi Sarawak selain sumber ekonomi utama, sektor minyak, gas asli, pembalakan dan perindustrian Hasil kajian mendapati, kerjasama antara Kerajaan Negeri Sarawak dengan Kerajaan Persekutuan berjaya meningkatkan KDNK menerusi jumlah pengeluaran dan eksport hasil pertanian di samping meningkatkan kualiti kehidupan rakyat Sarawak. Pembangunan infrastruktur telah memberikan keselesaan kepada penduduk Sarawak dalam skop masa kajian walaupun masih banyak lagi infrastruktur yang perlu, telah, sedang dan akan dibina selepas era pemerintahan Abdul Rahman Ya'kub sebagai Ketua Menteri Sarawak. Dalam masa yang sama, pembangunan infrastruktur secara keseluruhannya telah menjadi nadi kepada perkembangan ekonomi Sarawak melalui perkembangan sektor minyak dan gas, pembalakan, pertanian dan perindustrian. Hal ini didorong oleh kepesatan ekonomi dalam pelbagai industri ekoran kemudahan mengakses lokasi yang terletak jauh di luar bandar semakin baik berbanding terhadnya infrastruktur yang dibina 100 tahun dahulu ketika era pemerintahan Brooke diikuti British. Proses urbanisasi ini telah merubah cara hidup rakyat Sarawak kepada kehidupan yang lebih moden. Garis masa 1970 hingga 1981 menerusi dapatan perbincangan ini telah memberi mesej jelas bahawa sektor pertanian di Sarawak telah mengalami perubahan ketara kepada nilai eksport termasuklah peningkatan taraf hidup rakyat Sarawak yang menjadi asas dan panduan kepada pembangunan sektor pertanian Sarawak pada masa hadapan.

\section{Penghargaan}

Kami ingin mengucapkan penghargaan kepada pihak Universiti Malaya di atas sokongan terhadap penyelidikan Sub-Program Delta Sungai Sarawak Menurut Pandangan Penduduk Sarawak (RP001A-13HNE) di bawah kluster Humanities and Ethics (HNE) bertajuk 'Perkembangan Sektor Pertanian Di Sarawak, 1970-1981' serta orang perseorangan sama ada secara langsung atau tidak langsung dalam menyempurnakan penyelidikan dan penerbitan artikel ini 


\section{Nota}

*Emyzul Ismail (emyzul1975@gmail.com) merupakan calon Ph.D dari Jabatan Sejarah, Fakulti Sastera dan Sains Sosial, Universiti Malaya (UM).

** Dr. Arba'iyah Mohd Noor (arbaiyah@um.edu.my) merupakan pensyarah kanan di Jabatan Sejarah, Fakulti Sastera dan Sains Sosial, Universiti Malaya (UM)

${ }^{1}$ Muzium Perkayuan PUSAKA, Kuching, Sarawak.

${ }^{2}$ Fong Hon Kah, 1996. Sejarah Perkembangan Lembangan Rajang di Sarawak, Kuching: The Sarawak Press Sdn. Bhd., hlm. 1-2.

${ }^{3}$ Nor Diana Mohd Idris, "Penentu Sosioekonomi terhadap Pendapatan dan Kemiskinan Luar Bandar: Kajian Kes Projek Pembangunan Pertanian Bersepadu di Samarahan, Sarawak, Malaysia”, Jurnal Perspektif, Fakulti Ekonomi dan Pengurusan, Universiti Kebangsaan Malaysia, Jil. 5 Bil. 1 (1-18) ISSN 1985 - 496X

${ }^{4}$ The Economist Bulletin, Disember 1976, hlm. 51.

5 Awg Kasmurie Awg Kitot, Peranan Abang Yusuf Puteh Terhadap Pembangunan Masyarakat Melayu Sarawak 1970-2009, Tesis Kedoktoran, Jabatan Sejarah, Universiti Malaya, Kuala Lumpur, 2017, hlm. 290.

${ }^{6}$ Ranjit Singh, D.S. "Pertumbuhan Ekonomi Sarawak, 1824-1941", Sejarah, Jurnal jabatan Sejarah Universiti Malaya, No. 10. 2002, hlm. 78.

${ }^{7}$ Ibid., hlm. 79.

${ }^{8}$ Information on Sarawak, Borneo Literature Bureau, Kuching, 1960, hlm. 33.

${ }^{9}$ State Government and The Sarawak Foundation, Sarawak Maju Sejak Merdeka, Petaling Jaya: Kum Printers (tanpa tarikh)

${ }^{10}$ Fumitaka Furuoka, Economic Development In Sarawak, Malaysia: An Emperical Inquiry, Kota Kinabalu: Universiti Malaysia Sabah, 2011.

${ }^{11}$ Suhaimi Mokhtar, Putera Kenyalang: Satu Dekad Penuh Cabaran, Petaling Jaya: Penerbitan Pena Sdn. Bhd, 1981, hlm. 46.

${ }^{12}$ Hamid Bugo, The Economic Development of Sarawak: The effects of export instability, Kuching: Summer Times Publishing, 1984.

${ }^{13}$ The Economist Bulletin, Disember 1976, hlm. 51.

14 Ibid.

15 Ibid, hlm. 49.

${ }^{16}$ Sarawak Terus Membangun. Kerajaan negeri Sarawak., hlm. 7.

${ }^{17}$ Ibid.

${ }^{18}$ Sarawak Terus Membangun. Kerajaan negeri Sarawak, hlm. 7.

19 Wawancara bersama Datuk Dr. Haji Sanib Said pada jam 10 pagi bertarikh 11 April 2019 di Pejabat Amanah Khairat Yayasan Budaya Melayu Sarawak, Kuching, Sarawak.

${ }^{20}$ Sarawak Terus Membangun. Kerajaan negeri Sarawak. hlm. 7.

${ }^{21}$ Ibid, hlm. 8.

22 The Economist Bulletin, Disember 1976.hlm. 48.

${ }^{23} \mathrm{http} / / /$ www.bda.gov.my/modules/web/pages.php?lang=bm\&mod=webpage $\&$ sub=page $\& i d=59$ (tarikh diakses 3 Okt. 2019)

${ }^{24}$ Ibid.

${ }^{25}$ Abdul Jalil Ali, Sarawak 16 Tahun Dalam Malaysia, Kuala Lumpur: Jabatan Penerangan Malaysia, hlm. 125 .

${ }^{26}$ Disesuaikan dari (Tanpa penulis), Sarawak 20 Tahun 1963-1983, Sarawak Report, (tanpa tarikh), hlm. 250.

27 State Government and The Sarawak Foundation, Sarawak Maju Sejak Merdeka, Petaling Jaya: Kum Printers (tanpa tarikh), hlm. 54.

${ }^{28}$ State Government and The Sarawak Foundation, Sarawak Maju Sejak Merdeka, Petaling Jaya: Kum Printers (tanpa tarikh), hlm. 54.

${ }^{29}$ http://www.salcra.gov.my/en/about-us/greetings-from-salcra.html_(tarikh diakses 3 Okt. 2019)

${ }^{30}$ Ibid.

${ }^{31}$ Ibid.

${ }^{32}$ The Economist Bulletin, Disember 1976, hlm. 47.

${ }^{33} \mathrm{http}: / /$ www.salcra.gov.my/en/subsidiaries2.html (tarikh diakses 3 Okt. 2019)

${ }^{34} \mathrm{http}: / /$ www.salcra.gov.my/en/stakeholders-engagement/impacts-benefits.html_(tarikh diakses 3 Okt. 2019)

${ }^{35}$ http://www.salcra.gov.my/en/about-us/greetings-from-salcra.html_(tarikh diakses 3 Okt. 2019) 
${ }^{36}$ The Economist Bulletin, Disember 1976, hlm. 47.

${ }^{37}$ Council Negri Debates, Official Report, Third Meeting Of The First Session Of The Ninth Council Negeri, Kuching, $18^{\text {th }}$ December, 1975, hlm. 4-6.

${ }^{38}$ Ibid.

${ }^{39}$ Ibid, hlm. 6-7.

${ }^{40}$ Ibid, hlm. 23-24.

41 Wawancara Bersama Tuan Yang Dipertua Negeri Sarawak, Tuan Yang Terutama Tun Pehin Sri Haji Abdul Taib Mahmud di Kediaman Rasmi TYT Yang Dipertua Negeri Sarawak, Demak Jaya, Jalan Bako, Petra Jaya, Kuching, Sarawak pada jam 5.00 petang bertarikh 24 Julai 2019. Beliau menegaskan Tun Rahman, Stephen Yong dan Ong Kee Hui adalah antara individu penting yang bertanggungjawab dan berbincang masing-masing menerusi Parti SUPP, Panas dan Berjasa pada ketika itu berhubung usaha mewujudkan kerjasama untuk menuntut kemerdekaan bagi negeri Sarawak pada tahun 1963.

42 Wawancara Bersama Tuan Yang Dipertua Negeri Sarawak, Tuan Yang Terutama Tun Pehin Sri Haji Abdul Taib Mahmud di Kediaman Rasmi TYT Yang Dipertua Negeri Sarawak, Demak Jaya, Jalan Bako, Petra Jaya, Kuching, Sarawak pada jam 5.00 petang bertarikh 24 Julai 2019.

${ }^{43}$ Sarawak Tribune, 8 Mac 1977, hlm. 1.

${ }^{44}$ Council Negri Debates, Official Report, Third Meeting Of The First Session Of The Ninth Council Negeri, Kuching, $18^{\text {th }}$ December, 1975, hlm. 23-24.

${ }^{45}$ Ibid.

${ }^{46}$ Council Negri Debates, Official Report, Third Meeting Of The First Session Of The Ninth Council Negeri, Kuching, $18^{\text {th }}$ December, 1975, hlm. 23-24.

47 Abdul Jalil Ali, Sarawak 16 Tahun Dalam Malaysia, Kuala Lumpur: Jabatan Penerangan Malaysia (tanpa tarikh), hlm. 17.

48 Abdul Jalil Ali, Sarawak 16 Tahun Dalam Malaysia, Kuala Lumpur: Jabatan Penerangan Malaysia (tanpa tarikh), hlm. 17-18.

49 Zawani Anis Ismail, Tahap Pengetahuan Pelajar Aliran Pertanian Terhadap Bidang Pekerjaan Dalam Pertanian, Latihan Ilmiah, Fakulti Pendidikan, Universiti Teknologi Mara, 2011, hlm. 23.

${ }^{50}$ Ibid.

51 Zakariah Abdul Rashid, “Analisis Dasar Pertanian: Peranan Sektor Pertanian dalam Pelan Induk Perindustrian”, Jurnal Ekonomi Malaysia, Disember 1992, hlm. 116.

52 Abdul Jalil Ali, Sarawak 16 Tahun Dalam Malaysia, Kuala Lumpur: Jabatan Penerangan Malaysia (tanpa tarikh), hlm.68-69.

${ }^{53}$ Ibid.

${ }^{54}$ Ibid.

55 Ibid.

${ }^{56}$ http://www.salcra.gov.my/en/about-us/greetings-from-salcra.html_(tarikh diakses 20 Nov. 2019)

57 Abdul Jalil Ali, Sarawak 16 Tahun Dalam Malaysia, Kuala Lumpur: Jabatan Penerangan Malaysia, hlm.68-69.

58 Fong Hon Kah, Sejarah Perkembangan Lembangan Rajang Di Sarawak, Kuching: The Sarawak Press Sdn. Bhd., 1996, hlm. 399.

59 Zakariah Abdul Rashid, “Analisis Dasar Pertanian: Peranan Sektor Pertanian dalam Pelan Induk Perindustrian”, Jurnal Ekonomi Malaysia, Disember 1992, hlm. 116.

${ }^{60}$ Sarawak 20 Tahun 1963-1983, Sarawak Report, hlm. 51.

${ }^{61}$ Han Oo Kwang, Malaysia Kita : Ekonomi, Singapura: Times Books International, 1987, hlm. 28.

${ }^{62}$ Sarawak 20 Tahun 1963-1983, Sarawak Report, hlm. 51.

${ }^{63}$ The Sarawak Gazette, 31 Disember 1978, hlm. 262-263.

${ }^{64}$ Ibid.

${ }^{65}$ Rancangan Malaysia Ketiga: 1976-1980, 1976, hlm. 416.

${ }^{66}$ Ibid.

${ }^{67}$ Ibid.

${ }^{68}$ Rancangan Malaysia Ketiga: 1976-1980, 1976, hlm. 40.

69 Fong Hon Kah, Sejarah Perkembangan Lembangan Rajang Di Sarawak, Kuching: The Sarawak Press Sdn. Bhd., 1996, hlm. 429.

${ }^{70}$ Wawancara bersama Datuk Dr. Haji Sanib Said pada jam 10 pagi bertarikh 11 April 2019 di Pejabat Amanah Khairat Yayasan Budaya Melayu Sarawak, Kuching, Sarawak.

${ }^{71}$ Fail Bil: (2199) dlm YPS/P.29/230 (3.1.1975)

${ }^{72}$ Fail Bil: (2199) dlm YPS/P.29/230 (3.1.1975)

73 Ibid.

${ }^{74}$ Jomo K.S., Malaysia:Pembangunan, Ketidaksamaan, Perpaduan, Kuala Lumpur: Institut Pengajian 
Tinggi, Universiti Malaya, 1992, hlm. 70.

${ }^{75}$ Wawancara bersama Tuan Yang Dipertua Negeri Sarawak, Tuan Yang Terutama Tun Pehin Sri Haji Abdul Taib Mahmud di Kediaman Rasmi TYT Yang Dipertua Negeri Sarawak, Demak Jaya, Jalan Bako, Petra Jaya, Kuching, Sarawak pada jam 5.00 petang bertarikh 24 Julai 2019.

${ }^{76}$ Wawancara bersama Tuan Yang Dipertua Negeri Sarawak, Tuan Yang Terutama Tun Pehin Sri Haji Abdul Taib Mahmud di Kediaman Rasmi TYT Yang Dipertua Negeri Sarawak, Demak Jaya, Jalan Bako, Petra Jaya, Kuching, Sarawak pada jam 5.00 petang bertarikh 24 Julai 2019.

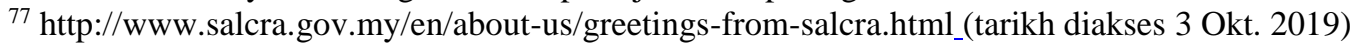

\section{Rujukan}

\section{Fail/Rekod/Akhbar}

Fail Bil: (2199) dlm YPS/P.29/230 (3.1.1975)

Council Negri Debates, Official Report, Third Meeting Of The First Session Of The Ninth Council Negri, Kuching, $18^{\text {th }}$ December, 1975.

Potret Anak Watan, Filem Negara Malaysia (Kaset Video), MKSV 1895.

Rancangan Malaysia Ketiga: 1976-1980, 1976.

Sarawak 20 Tahun 1963-1983, Sarawak Report.

Sarawak Tribune, 8 Mac 1977.

The Economist Bulletin, Disember 1976.

The Sarawak Gazette, 31 Disember 1978.

\section{Buku}

Abdul Jalil Ali, Sarawak 16 Tahun Dalam Malaysia, Kuala Lumpur: Jabatan Penerangan Malaysia.

Abdul Rahman Ya'kub, Surat Terbuka Tun Abdul Rahman Ya'kub kepada Tan Sri Abdul Taib Mahmud, Kuala Lumpur: Syarikat Alat Tulis Soorama, 1991.

Fong Hon Kah, Sejarah Perkembangan Lembangan Rajang Di Sarawak, Kuching: The Sarawak Press Sdn. Bhd., 1996.

Han Oo Kwang, Malaysia Kita : Ekonomi, Singapura: Times Books International, 1987.

Information on Sarawak, Borneo Literature Bureau, Kuching, 1960.

Jomo K.S., Malaysia:Pembangunan, Ketidaksamaan, Perpaduan, Kuala Lumpur: Institut Pengajian Tinggi, Universiti Malaya, 1992. 
Sarawak Terus Membangun, Kerajaan Negeri Sarawak.

Sulaiman M. Yassin, Pembangunan Di Bumi Kenyalang: Satu Kajian Persepsi Rakyat, Serdang: Universiti Pertanian Malaysia, 1994.

Zakariah Abdul Rashid, "Analisis Dasar Pertanian: Peranan Sektor Pertanian dalam Pelan Induk Perindustrian”, Jurnal Ekonomi Malaysia, Disember 1992.

\section{Tesis/Latihan Ilmiah/ Artikel Jurnal}

Awg Kasmurie Awg Kitot, Peranan Abang Yusuf Puteh Terhadap Pembangunan Masyarakat Melayu Sarawak 1970-2009, Tesis Kedoktoran, Jabatan Sejarah, Universiti Malaya, Kuala Lumpur, 2017.

Nor Diana Mohd Idris, "Penentu Sosioekonomi terhadap Pendapatan dan Kemiskinan Luar Bandar: Kajian Kes Projek Pembangunan Pertanian Bersepadu di Samarahan, Sarawak, Malaysia", Jurnal Perspektif, Fakulti Ekonomi dan Pengurusan, Universiti Kebangsaan Malaysia, Jil. 5 Bil. 1 (1-18) ISSN 1985 - 496X

Ranjit Singh, D.S. "Pertumbuhan Ekonomi Sarawak, 1824-1941”, Sejarah, Jurnal Jabatan Sejarah Universiti Malaya, No. 10. 2002.

Zawani Anis Ismail, Tahap Pengetahuan Pelajar Aliran Pertanian Terhadap Bidang Pekerjaan Dalam Pertanian, Latihan Ilmiah, Fakulti Pendidikan, Universiti Teknologi Mara, 2011.

\section{Wawancara}

Wawancara bersama Datuk Dr. Haji Sanib Said pada jam 10 pagi bertarikh 11 April 2019 di Pejabat Amanah Khairat Yayasan Budaya Melayu Sarawak, Kuching, Sarawak.

Wawancara bersama Tuan Yang Dipertua Negeri Sarawak, Tuan Yang Terutama Tun Pehin Sri Haji Abdul Taib Mahmud di Kediaman Rasmi TYT Yang Dipertua Negeri Sarawak, Demak Jaya, Jalan Bako, Petra Jaya, Kuching, Sarawak pada jam 5.00 petang bertarikh 24 Julai 2019.

\section{Sumber Internet}

http://www.bda.gov.my/modules/web/pages.php?lang=bm\&mod=webpage \&sub=pa ge\&id=59 (tarikh diakses 3 Okt. 2019)

http://www.salcra.gov.my/en/subsidiaries2.html (tarikh diakses 3 Okt. 2019)

http://www.salcra.gov.my/en/stakeholders-engagement/impacts-benefits.html (tarikh diakses 3 Okt. 2019)

http://www.salcra.gov.my/en/about-us/greetings-from-salcra.html (tarikh diakses 3 Okt. 2019) 